https://helda.helsinki.fi

Trapped in university rankings : bridging global competitiveness and local innovation

\title{
Erkkila, Tero
}

2020-04-02

Erkkila , T \& Piironen , O 2020 , ' Trapped in university rankings : bridging global competitiveness and local innovation ', International Studies in Sociology of Education, vol. 29 , no. 1-2 , pp. 38-60 . https://doi.org/10.1080/09620214.2019.1634483

http://hdl.handle.net/10138/326489

https://doi.org/10.1080/09620214.2019.1634483

acceptedVersion

Downloaded from Helda, University of Helsinki institutional repository.

This is an electronic reprint of the original article.

This reprint may differ from the original in pagination and typographic detail.

Please cite the original version. 


\title{
Trapped in University Rankings: Bridging Global Competitiveness and Local
}

\section{Innovation}

\author{
Tero Erkkilä \\ Faculty of Social Sciences \\ University of Helsinki \\ Email: tero.erkkila@helsinki.fi \\ Ossi Piironen \\ Ministry for Foreign Affairs \\ Government of Finland \\ Email: ossi.piironen@formin.fi
}

\section{Biographical notes}

Tero Erkkilä is Associate Professor of Political Science at the University of Helsinki. His previous publications include Government Transparency (Palgrave 2012), Global University Rankings (Palgrave 2013), Public Administration (Routledge 2015, together with B. Guy Peters and Patrick von Maravic) and Global Knowledge Governance (Palgrave 2018, together with Ossi Piironen).

Ossi Piironen (D.Soc.Sc.) is Senior Researcher at the Ministry for Foreign Affairs of Finland. Piironen has published in various peer reviewed journals and has several years of experience in teaching issues of global governance and methodology of political science at the Department of Political and Economic Studies, University of Helsinki.

\section{Funding details}

This research has received funding from the Academy of Finland, being part of the project Policy Instruments and Global Governance: Concepts and Numbers (grant number 268181).

\section{Acknowledgements}

We would like to thank our reviewers for their excellent comments. We thank the Academy of Finland for funding our research (grant number 268181).

\footnotetext{
Abstract

For over a decade, global university rankings have played a growing role in the status competition in higher education. More recently, we have seen a proliferation in rankings of innovation and urbanization. In this article, we argue that while these new measurements bring with them some conceptual adjustments, they draw heavily on existing rankings and embrace the embedded competitive logic. Local rankings of innovation objectify higher education as an element of global competitiveness. Furthermore, we argue that this logical shift is made with the help university rankings that now come to bridge global competition and local innovation; the existing global university rankings are directly used in the composite indicators of local innovation or their methodology is copied. Consequently, political imaginaries of global competition are now projected to regional and city level.
} 


\section{Introduction}

The perceived value of excellence in higher education and academic research has been linked to the political imaginary of global competitiveness (Marginson, 2008; Mittelman, 2017). For over a decade, global university rankings have played a growing role in feeding the status competition between both higher education institutions and governments alike. More recently, however, we have seen a proliferation in rankings of innovation and urbanization. In this article we argue that, while the new measurements bring with them some conceptual adjustments by shifting the analytical focus on local-urban actorhood, they draw on the existing rankings and embrace the embedded competitive logic by which the neoclassical economics premise of competition leading to optimal overall outcome is extended to govern various policy domains.

We further argue that the rankings of universities and research performance now provides an ideational - or operational - bridge between global competitiveness and urban innovativeness. Rankings of innovation reduce universities and academics as components in global competition between urban areas as hot-beds of innovation, implying a new idea with assumed utility. This article shows how the regional and city level innovation rankings rely heavily on existing university rankings as sub-national data sources while rest of their data is drawn from the country level governance indicators or approximations based on them. Hence, the existing rankings strongly influence the future measurements, not only through shared epistemic knowledge, but also through data sets as resources on which future indicators are built. What has been measured conditions what can be measured.

The assessment of 'local' innovativeness would hardly be possible without the existing university rankings as available data source. The new indicators of local innovation and 
competitiveness become trapped in the existing global university rankings, without which there would be no local level measurements of innovation in a meaningful sense.

Furthermore, the new indicators of local innovation strengthen the established order of ranking instead of providing alternatives to it. Hence, the global university rankings help to transfer the global imaginaries of competition to regional and local level. Analyzing the prominent city-level measurements of competitiveness and innovation, this article explores the above ideational shifts of innovation that highlight the intensifying coupling of higher education and economic competitiveness, now traversing the different levels of assessment. We claim that these shifts are important as quantification comes to objectify the thing which is measured - rendering it governable and open for policy intervention. The indicators firmly now tie local innovation and higher education with (global) competitiveness.

Along with objectification, the numbers - statistics, quantitative data, index scores - acquire their governance effects through subjectification, where individuals, actors and entities come to acquire socially constructed identities that are further linked with calls for action. This is apparent in the rise of city level measurements, as the ranking producers now argue for urbanization as a major global trend that is decisive for competitiveness and innovation, embodied in global higher education. But while the rhetoric highlights a revolution, the actual measurements to observe and construct this development are largely based on existing figures, now simply projected to regional level with the help of university rankings.

Our article builds on previous research that has highlighted field development in global ranking and the ideational inter-connectedness between the different indicators and their producers (Erkkilä \& Piironen, 2018). This involves competition and classification struggles between knowledge producers, but also close collaboration that leads to conformity, 
(seeming) depoliticization of the measurements and lack of true alternatives in the field of global ranking, as the ranking producers share much of the same premises, methods as well as data (Erkkilä \& Piironen, 2014; Kauppi \& Erkkilä, 2011). The above research has mostly addressed the surge of global rankings over the past two decades in various policy domains, whereas we wish to draw attention to the rise of measurements of innovation that arguably provide an alternative to the existing rankings, especially by focusing on regions and cities instead of ranking countries. Throughout the paper we explore what added value the new rankings of innovation have, considering also their recent focus on local level, and what implications this has for governance of innovation.

We observe that the new local and regional level measurements of innovation draw heavily from global indicators as data sources and ideational references. Instead of being an alternative to global rankings, the local measurements of innovation are rather a result of them. Most apparently, the global university rankings now allow the step to local level and towards measurement of local innovation, linking this to the debates on global competitiveness. This objectifies a policy issue of "local innovation", rendering it governable. Through subjectification, local innovation is further framed as a response to major changes such as global urbanization and rise of automation that now call for action.

We next present our theoretical frame in more detail. We will begin our empirical investigation by showing how the country rankings of innovation and competitiveness overlap. We will then move to observe a similar trend in regional and city level measurements, highlighting the role of university rakings in enabling the shift of analytical focus to 'local' innovation, making it governable. Finally, we will assess subjectification as a mechanism of change by exploring data producers accounts on the implications of their 
rankings. Here we observe knowledge producers' use of grand narratives of 'revolution' in urban innovation that stands in a stark contrast with the strong continuity and convergence in data production. We conclude that as a key data source, the university rankings have allowed the ranking of innovation to move to local and regional level, now also rendering this as a governable policy domain that demands action amid global competition.

\section{Objectifying Innovation, Subjectifying Urban Entities}

Comparative measurement has become a powerful tool in recent decades. More than simply mirroring the concepts they intend to quantify, indicators, on many occasions, have come to define the very meaning of the concepts in the first place: quantification functions to fix the parameters of ideas, ideals and imaginaries thus creating specific representations that may (or may not) influence practices and policies, and the formation of subject categories and identities. The significance of measurement as a technology of truth may be due to its capacity to simplify otherwise complicated matters, conceal subjective, interested, partisan, perspectival choices, and create an impression of objectivity, neutrality, credibility and universality (Porter, 1996; Power, 2003). Thus, and following the vocabulary of Desrosierès, we see the socio-political measurements as instruments of objectification (Desrosières, 1998, p. 9). Numbers work as technologies that make objects visible and tangible, bordered and governable (Miller \& Rose, 1990; Robson, 1992).

The production of comparative numbers is not only a descriptive but also an evaluative and often normative exercise. Measurement does not only make things visible, but provides a technique for judgment, as well as punishment and gratification (cf. Hoffmann, 2011). Measurements and indices acquire a political function in promoting a certain conceptualization of policy-relevant ideas over alternatives. Although struggles in designing 
new measurements are relatively common - Le Bourhis (2016), for example, illustrates how various interests collided in French and European endeavors to construct sustainability and environmental indicators - and even though new statistics sometimes have a potential for opening new political horizons, often the opposite is true. New numbers challenge dominant ones only to the extent that they come to reinforce each other's legitimacy (Erkkilä \& Piironen, 2014).

To understand the dynamics of knowledge creation in ranking, one also needs to consider the ranking producers as actors. Lim has referred to "weak expertise" in explaining the position of university ranking producers, where they engage in a balancing act between relevance, reliability and validity of their data (Lim, 2018). To keep up legitimation, such expertise needs to be constantly renegotiated with key stakeholders but also the critics of rankers, including competing knowledge producers. Such classification struggles (Kauppi \& Erkkilä, 2011) can be observed in various domains of global ranking, often being instrumental for the organizations involved. In the context of poverty reduction, Freistein has observed how index producers' competition over limited resources is also projected in their willingness, and outright pressure, to produce data sets (Freistein, 2016). While the scientific basis of global rankings is often criticized (Broome, Homolar, \& Kranke, 2018), the boundary work on scientific validity is often at the heart of competition and collaboration between different knowledge producers (Erkkilä \& Piironen, 2014).

In fact, as our analysis shows, the existing global indicators largely come to set the boundaries to the future data sets: their ideological elements, normative and causal beliefs, rites of validity, methodological choices and even data sources. The existing figures form the core of knowledge (Haas, 1992) that the actors entering the field will have to validate their 
data sets against. There is hence a strong tendency for convergence between the different measurements. This might be somewhat unintended (Baert, 1991; Giddens, 1984) or outright strategic, meaning that the new index producers entering the field use the existing methods, data and rites of validity as epistemic capital (cf. Alasuutari, Rautalin, \& Syväterä, 2015) when promoting their new knowledge products. Examining the indicators and data sources of the new measurements of innovation, we explore how they function to link human capital and knowledge production closely to economic competitiveness, through the heavy use of existing concepts and data, as well as sharing the normative and causal beliefs.

The way indicators are composed is important as this objectification renders ambiguous and often subjective ideas and concepts into well-defined and collectively shared knowledge products making them governable and marking an opening - or even need - for policy intervention. Furthermore, the attributes of indicators also point out mission statements: what to improve to fare better in the rankings. Indeed, capability to foster innovative ecosystems is valuable only in relation to the corresponding capabilities of similar entities. An analysis of attributes and indicators of a data set exposes the assumptions defining a thriving innovation ecosystem. Moreover, as the focus of measurement is shifting from national level towards cities and urban areas, local innovation hubs are identified as the drivers of economic prosperity. In other words, objectification is played out in outlining the perceived attributes of a successful global city that is inherently linked to global economic competition through innovation and knowledge production. Rankings construct a political imaginary of competition while creating goals to achieve and implying policy models to follow.

Another mechanism through which the rankings obtain their governing effects is subjectification - the process by which entities acquire, or are incentivized, enticed and 
pressured to acquire, particular identities. It is a process where classifications, often obtained through measurements, are linked to collectively produced identities: "the social self is a product of relations with others" (Lawler, 2014, 6). These classifications - subject categories - often imply rules and norms that go with a particular identity (Lawler, 2014, p. 69). As such, identification is linked to power and government. Global indicators imply identities and patterns of identification related to ranked entities, for example as citizens of a country or university employees, now engaged in global competition.

Sociopolitical quantification in the form of rankings affects identification in two elementary ways, through evaluation and atomization. Firstly, by associating particular agents with categories or identity groups as, for example, "one of the least developed countries", "a semidemocracy", "low in corruption", "highly performing". These categories then affect how the categorized entities are being treated, expected to behave and how they actually see themselves and behave. It could be argued, for example, that meagre results in global university rankings have played a role in policy changes in Europe over the past decade or so (Hazelkorn, 2011; Kehm \& Stensaker, 2009). More than a result of external pressures, the changes have come about through European reflexivity over measured low performance of academic institutions and individuals.

As intended by their producers, measurements of innovation entice decision-makers to adopt policies presumably improving the capability to boost innovation. Measured subjects such as cities are under external evaluation and self-discipline. Success and failure are mercilessly exposed in ranking scores. Rankings play an even more profound role in identity formation as they help in constructing particular kinds of subjects: autonomous, capable and responsible. Measurement constructs a social atomistic representation by projecting an explicitly 
autonomous social subjectivity, expected to self-govern and participate in co-governing. Techniques such as numeric assessment, while celebrating the autonomy of the entities under evaluation, simultaneously subject them to government.

There is increasing consensus about the potential effects of global rankings on national policies (Espeland \& Sauder, 2007; Kelley \& Simmons, 2015; Merry, Davis, \& Kingsbury, 2015). But with the proliferation of global rankings with organisations, regions and cities as units of observation, the institutional effects spill beyond national aggregates. According to Miller and Rose, numbers establish "government at a distance" that is especially linked to the liberal forms of indirect rule in which technologies and vocabularies are used to assemble agents into self-governing networks of affiliation (Rose \& Miller, 2008, p. 34). Numbers not only create a common sphere of interaction and an imagery of unity in comparability, they contribute to subjectifying individuals and collectivities as free agents capable of governing themselves in the optimal pursuit of desired results (Löwenheim, 2008).

Subnational measurements of innovation propose common interests and objectives that should guide the actions of local decision-makers, with responsibility for success or failure on their own shoulders alone (cf. Kangas, 2017). Through global comparison local actors are thus bound more tightly into transnational networks of self-governing. Simultaneously, however, the measurements pose a challenge to the state-centric understanding of global governance as urban areas are represented as hot-beds of innovation. The methodological development - the switch from country-level to city-level - is ideationally justified by resorting to historical narratives, references to past thinkers and eras, and the evidence of grand global trends. 
In the following empirical analysis, we show that while the rhetoric to promote the city level measurements of competitiveness and innovation speaks to a revolution in political economy of knowledge, the emerging measurements themselves, on the contrary, are characterised by strong continuation and ideational conventionality. Analysing more closely measurements of local competitiveness and innovation, this paper argues that the university rankings have come to serve as a bridge between global and regional measurements. University rankings focus on higher education institutions rather than national systems and as such cannot fully assess regional differences in higher education. But as innovation hubs are often centred on higher education institutions residing in metropolitan areas, the university rankings and their methodology become a logical element in the new sub-national measurements of competitiveness and innovation.

\section{Measuring Competitiveness and Innovation: Convergence and Conceptual Overlap}

Numerical objectification has fundamentally influenced the knowledge production of international organizations and NGOs, which are now compelled to have data sets of their own. At present, scholars observe a field development in global measurement (Erkkilä \& Piironen, 2018; Grek, 2013; Kauppi \& Erkkilä, 2011), leading to multiplication and fragmentation of measurements assessing the national production and governance of knowledge. Moreover, there are similar paths of development in the rankings of state knowledge in different policy domains. Most notably, we observe a fragmentation of rankings and indicators relevant to knowledge governance in higher education, economic competitiveness, innovation and good governance. This is caused by new indicator sets and actors entering the global field of numerical assessment. 
When arguing that there is a need of yet another indicator, ranking producers seek to show that existing figures contain inadequacies. But most noticeably the above critique serves as a stepping-stone for new actors to produce alternative figures. While the critique of existing indicators in terms of their methodology and scope allows new actors to enter the field with their alternative sets of indicators, it also further embeds the use of numerical assessment in transnational governance. Actors wishing to join the activity of governance measurements need to legitimate their knowledge products according to the criteria set by the existing epistemic community (Gieryn, 1983; Haas, 1992). As a result, new indicators are likely to conform to existing normative and causal beliefs and criteria of validity. We witness this in the shift towards rankings of regions and cities that have come to complement the indicators of global scope and in the novel concepts of measurement such as innovation.

Table 1 below shows three prominent global measurements of competitiveness and innovation. The World Economic Forum's (WEF) Global Competitiveness Index was first published in its current form in 2004, but the WEF has been measuring competitiveness since 1976, helping it to become the most prominent global knowledge provider on competitiveness. Global Innovation Index by Cornell University, INSEAD, and the World Intellectual Property Organization (WIPO) was first published in 2007, claiming to extend the conceptualisation of global ranking to "innovation". Following these two, the Global Talent Competitiveness Index was launched in 2013, published by INSEAD, Adecco and Human Capital Leadership institute. It claims to measure countries' ability to attract and retain human capital, necessary for competitiveness and innovation.

[Table 1 here] 
While the three indicators claim to measure three different concepts, their conceptual similarities are striking as is the overlap in their sources of data. As table 1 shows, $87 \%$ of all variables in the three data sets have been produced by ten organisations. ${ }^{1}$ This demonstrates how heavily the existing data sets steer the numerical knowledge production, not only conceptually but also in terms of strong convergence in sources of data. In many ways, the existing data sets provide boundaries to the future data sets; what has been measured is closely linked to what "can be" measured.

Along global measurements of innovation, regional and city-level measurements of competitiveness and innovation have risen to highlight the concern over ones' performance that many governments now share. However, there is also increasing awareness that the different aspects of competitiveness and innovation tend to privilege institutional arrangements that are also stem from certain cultural and ideological premises. This can lead to attempts at improving their methodology or providing alternative data that would better fit local realities. But again, there is the instrumental aspect of providing measurements that directly assess the local conditions for innovation in a specific region or the performance of cities instead of nations. This objectifies and constructs local innovation as an issue of concern, marking an opening for policy interventions. As our analysis below shows, through heavy referencing of previous measurements and use of existing data, the new regional indicators become hostages of what has been measured before, ultimately also influencing the policy problems that arise with the help of these indicators.

\footnotetext{
${ }^{1}$ This does not mean that the three indicators contain exactly the same variables, but that $87 \%$ of the data used in them originated from same ten organizations.
} 


\section{Ranking Competitiveness and Innovation of Cities and Regions: Links to Existing}

\section{Measurements}

Complementing the existing global rankings, the measurements of local innovation and competitiveness often hold cities as the subject of their analysis, instead of focusing on countries or universities (Table 2 and Table 3). Such rankings typically include assessments of knowledge, talent and human capital. The city level rankings have objectified local innovation as a novel policy problem, but a closer look at these indicators shows the legacy of previous global rankings, visible in their producers, concepts and attributes as well as sources of data.

Looking at the table 2, we see that there are a number of new data producers in the field of measurement, along with the World Economic Forum, which have produced a prominent global ranking already earlier. There are also other recognized authorities among the producers of city rankings on competitiveness, most notably the Economist Intelligence Unit. Other organizations that produce such measurements are mostly private companies and consulting firms (MasterCard, A.T. Kearney), business information providers (CrunchBase, Compass), and non-profit organizations (the Mori Memorial Foundation).

[Table 2 here]

The prominent global measurements of competitiveness, most notably by the World Economic Forum, have mostly gone unchallenged. However, the first subnational competitiveness measurement, the Worldwide Centers of Commerce Index by MasterCard, was first published in 2007-2008. The development continued in 2008 with the appearance of A.T. Kearney and the Mori Memorial Foundation, shortly followed by the EU Regional 
Competitiveness Index (2010), Hot Spots 2025 (2013) and Competitiveness of Cities report (2014). These data sets supplement the earlier measurements of competitiveness, but also provide a broader context for analyzing higher education and academic research. The Startup Ecosystem Report (first published 2012) by Crunchbase and Compass measures startup ecosystems referring to metropolitan cities or geographic regions with shared pool of resources. This shows a novel focus in the fabric of competitiveness, namely the ecosystem of various actors, both private and public.

The table 3 shows a sample of subnational innovation rankings. The European Union's Innovation Union Scoreboard was published already in 2001, in the wake of the EU's Lisbon strategy. Now titled European Innovation Scoreboard, it also includes other European countries outside the European Union. The annual report also contains a brief section on the global standing of the EU as a bloc vis-à-vis its competitors such as the US and the BRICS countries (European Commission, 2016). There are also new innovation indexes that focus specifically on cities, such as the Innovation Cities Index, published by 2 thinknow, which was first launched in 2007, measuring "cities potential as innovation economies".

[Table 3 here]

In terms of conceptualization, data and methodology, the young city rankings resemble early measurements of good governance, which were composite indicators, using data from various sources (Knack, Kugler, \& Manning, 2003; Langbein \& Knack, 2010). However, there is also a concrete link in data sources, as these city-level measurements mostly use available public data sources, instead of producing data themselves. The global good governance indicators now provide major share of the data sources used by the city rankings. 
For instance, A.T. Kearney's Global City Index uses country data in the absence of city-level data and borrowing from one another (Leff \& Petersen, 2015, p. 12). A.T. Kearney's does not publish its data sources, but there are clear links to existing governance indicators. The Global City Index (A.T. Kearney 2015) contains a dimension of Information Exchange (15 per cent of the rank score), linking it ideationally to the measurements of transparency and good governance. Though the data sources are not named, A.T. Kearney's data appendix indicates that its Information Exchange dimension also includes freedom of expression (A.T. Kearney, 2014, p. 14). There is at least a conceptual link to the measurements of Freedom House. The Governance dimension of the Global Cities Outlook contains indicators on transparency, quality of bureaucracy, and ease of doing business, which also bear close ideational resemblance to the World Bank's Worldwide Governance Indicators and Ease of Doing Business ranking. A.T. Kearney also appears as a 'knowledge partner' in the Global Innovation Index 2015 report (Cornell University, INSEAD and WIPO, 2015, Chapter Preface).

Also the Government \& Politics segment of the Innovation Cities Index (2thinknow) contains many ideational elements similar to the good governance indicators, stressing government responsiveness, transparency, open data and eGovernment initiatives, but again the sources are not named. It is further specified that "[2thinknow] also take national rankings and through our standard process acclimatise and adapt them to city indicators." 2 The above statements highlight the issues of using national level data in city level measurements, but also the limited public documentation of the measurements.

\footnotetext{
${ }^{2}$ 2thinknow Data Types, [http://www.citybenchmarkingdata.com/data-types]
} 
The Regional Competitiveness Index of the European Union measures the competitiveness of regions within EU member states based on the so-called NUTS 2 regional categories. In terms of methodology the Regional Competitiveness Index "builds on the approach of the Global Competitiveness Index by the World Economic Forum" (Paola Annoni, Dijkstra, \& Gargano, 2017, p. 2), and aims for a holistic perspective. In its measurements of national institutions, the EU's Regional Competitiveness Index uses data from the World Bank's Worldwide Governance Indicators (all six dimensions), the World Bank's Ease of Doing Business scores for the countries measured, as well as selected (eight) indicators from the WEF's Global Competitiveness Index. ${ }^{3}$ In similar fashion, the 'Economy' function of Mori Memorial Foundation's Global Power City Index also draws sources from existing indicators such as World Bank's Ease of Doing Business, Moody's credit rating, Heritage Foundation's Index of Economic Freedom, and the Global Talent Competitiveness Index by INSEAD.

The new regional and city-level measurements are not very specific in nature, as they often aim at making general assessments of very abstract concepts of innovation and competitiveness. This is somewhat surprising, as the closer geographical focus on cities would in principle allow the city rankings to aim for a specificity of indicators. But the result is the opposite, as the city-level measurements are mostly composite indicators that often base their analysis on available country data. Their producers have limited resources to collect city-level data themselves and are probably therefore compelled to use available country data instead. This further solidifies the links between the previous measurements and the emerging city indicators, which in conceptual terms alone are closely aligned to the premises and causal and normative beliefs standing in the field of global ranking.

\footnotetext{
${ }^{3}$ The EU Regional Competitiveness Index 2016: indicators description [http://ec.europa.eu/regional_policy/sources/docgener/work/rci2016_indicators.xls]
} 
In short, as the examples above indicate, the city level competitiveness indicators build directly on previous global measurements of competitiveness and innovation. But what then makes them stand out in their analysis, is their use of university rankings or imitations of them. This allows them, at least at the level of argument, to focus on innovation hubs and major cities where the global knowledge production mainly takes place. But even here, however, the objectification of innovation seems to become a hostage of existing data.

Knowledge, Competitiveness and Innovation: Global University Rankings Bridging Levels of Analysis

The measurements of local competitiveness and innovation strongly overlap in their assessment of knowledge. As seen in see table 2, the assessment criteria of city level indicators on competitiveness now contain broad categories to measure knowledge and education. These include elements such as "human capital" (Hot Spots 2025, A.T. Kearneys Global Cities), "soft-connectivity" (Competitiveness of Cities), "talent" (The Startup Ecosystem Report), “information exchange and innovation” (A.T. Kearneys Global Cities), "research and development" (Global Power City Index), and "knowledge creation and information flow" (Worldwide Centers of Commerce Index).

The university rankings are harnessed as a convenient way to provide an ideational bridge between the different level of analysis, allowing the assessments of local innovation hubs centered around universities located in major cities and urban areas. The Human Capital dimension comprises 30 per cent of A.T. Kearney's Global Cities Index. The 2014 report opens the Human Capital dimension by stating that it “evaluates a city's ability to attract talent based on the following measures: size of foreign-born population, quality of 
universities, number of international schools, international student population, and number of residents with university degrees." (A.T. Kearney, 2014, p. 14). The quality of universities sub-indicator has a clear ideational link to university rankings, but the exact data source is not named.

The World Economic Forum's taxonomy underlying the Competitiveness of Cities (World Economic Forum, 2014a, p. 5), contains education and training systems as one of its highlighted elements (World Economic Forum, 2014b, p. 13). This bears ideational similarities to measurements on higher education. The EU's Regional Competitiveness Index's measures for education are mostly from Eurostat, though also OECD PISA results are used for basic education. The indicators on innovation come predominantly from Eurostat except for the scientific publications indicator that is based on Scopus data, which is also used in university rankings. The European Innovation Scoreboard's assessment of innovation environment (Enablers) similarly contains various indicators from data producers feeding also global university rankings.

The Innovation Cities Index by the 2thinknow builds on three factors: Cultural Assets, Human Infrastructure and Networked Markets, which are further divided into 31 segments and 162 indicators. Its list of standard indicators shows apparent similarities between the measurements of city competitiveness, though there are also other elements that measure "general livability". Knowledge and education also feature prominently in the indicator, particularly visible in the Education, Science \& Universities segment, that has indicators on different types of education programs (arts and business education), science and engineering facilities and competitive position of city, and university commercialization in terms of 
technological innovations. The organization notes that its "indicators rely on rankings for universities, cities, businesses and industries that are then adapted to be city-level data." ${ }^{4}$

The university rankings and their methodology are conspicuous in the measurement of innovation. This is apparent in the innovation measurements of Thomson Reuters, the current producer of the THE ranking, and Clarivate Analytics (formerly known as Thomson Reuters Intellectual Property \& Science). Building on patent data, the Top 100 Global Innovators measures the innovation performance of organizations in terms of volume, success, globalization, and influence of innovations patented by the organization. The use of patent data as a proxy for innovation is also commonplace for the measurements of innovation and competitiveness.

The Mori Memorial Foundation's Global Power City Index includes indicators for Academic Resources, Research Background, and Research Achievement (The Mori Memorial Foundation, 2016, pp. 356-357). These strongly refer to existing country data as well as global university rankings. The Times Higher Education's World University Rankings is used as a source for the "World's Top 200 Universities" indicator in Academic Resources but the THE rankings sub-scores also provide data for the "Readiness for Accepting Researchers" indicator in the Research Background indicator group, though this is also complemented by questionnaires. Also, the UNESCO country data is used in assessing both number of researchers (Academic Resources) and research and development expenditure (Research Background). The OECD's Programme for International Student Assessment (PISA) average science and math literacy country scores are used for the cities residing in that country (Research Background). The Research Achievement indicator Number of Winners of Highly-

\footnotetext{
${ }^{4}$ 2thinknow Data Types, [http://www.citybenchmarkingdata.com/data-types]
} 
Reputed Prizes bears great resemblance to the ARWU (Shanghai list) sub-indicators that count winners of Nobel Prizes and Fields Medals, though the measure by Mori Memorial Foundation includes three other science and technology awards. In the Research Achievement category, number of patents is also assessed. This is a relatively standard element in assessments of innovation, but again it is counted by using an estimate based on country data.

Our examples show how regional measures of innovation are increasingly difficult to distinguish from rankings of universities, as they use similar bibliometrical data and methodology, though often combined with patent information. It is also interesting to note that the Thomson Reuters Top 100 Innovative Universities measurement, has also led to two further measurements: Europe's Most Innovative Universities ${ }^{5}$ and Asia's Most Innovative Universities. ${ }^{6}$ These regional rankings are based on the Top 100 Innovative Universities ranking, with slight modification of the methodology.

To summarize, the measurements on competitiveness and innovation are very much aligned. Moreover, the rankings on city competitiveness and innovation increasingly overlap with university rankings. Looking at the matter from the perspective of competitiveness, innovation and higher education, there is now a whole range of measurements reaching from global to city level that objectify knowledge governance as a policy concern for countries, innovation hubs and cities. The regional and city level innovation rankings rely on existing university rankings as one of their few sub-national data sources while rest of their data consists of country level governance indicators or approximations based on them. The

\footnotetext{
${ }^{5}$ Thomson Reuters Europe's Most Innovative Universities [http://www.reuters.com/most-innovativeuniversities-europe]

${ }^{6}$ Thomson Reuters Asia's Most Innovative Universities [http://www.reuters.com/most-innovative-universitiesasia-2016]
} 
existing university rankings bridge the different levels of measurement and the assessment of 'local' innovativeness would hardly be possible without university rankings as available data source. Consequently, the global university rankings help to transfer the global imaginaries of competition to regional and local level.

\section{Political Imaginaries: Local Innovation, Global Competition}

To enter the field of knowledge production, the organizations that produce regional and citylevel indicators must again make a case for a specific need for their indicators. The measurements of local innovation and competitiveness arguably complement the existing global measurements by introducing a new level of measurement: the city. Along with objectification (see above), rankings of local innovation and competitiveness acquire their governance effects through subjectification, where indicators help to construct social identities for urban actors that are further linked with calls for action. The producers of city level rankings now argue for global urbanization as a major trend in competitiveness and innovation, embodied in global higher education. Here political imaginaries of competition are also rife with historical references to "urbanization" with future implications (cf. Hobsbawm, 1987; Koselleck, 2004).

Already in 2008, MasterCard identified urbanization as a global process that demands new types of measurements focusing on cities. This is cited as a motivation for developing the Centers of Commerce Index (Mastercard, 2008, p. 1). In 2013, the Economist Intelligence Unit argued in the executive summary of its Hot Spots 2025 ranking for the centrality of cities in the global economy. Juxtaposing past with future (The Economist Intelligence Unit, 2013 , p. 2), it refers to urbanization as a development that warrants a measurement focusing 
on cities. Also A.T. Kearney's Global Cities measurements are promoted with the same rationale - urbanization requires measurements of its own (A.T. Kearney, 2015, p. 1).

The rise of subnational competitiveness indicators can also be read as a critique of the existing global rankings on competitiveness, where the focus on countries as units of analysis has come to overlook the real actors, cities. It is therefore interesting to note that the World Economic Forum - the expert organization on global competitiveness as the producer of the Global Competitiveness Index - started to produce an assessment on city competitiveness in 2014. The WEF outlines its new city assessment in the 2014-2015 Global Competitiveness Report, depicting it as "recognition" of "other geographical levels" (World Economic Forum, 2014a, p. 4). Again, the grand narrative of urbanization is reproduced by the World Economic Forum in its Competitiveness of Cities report (World Economic Forum, 2014b, Chapter Preface).

The discourse on urbanization speaks for a path-breaking development that concerns the future, but there are keen references to the past resembling Hobsbawm's invention of traditions (Hobsbawm, 1987). The historical narratives of cities and the political imaginaries of the global economy are evoked by knowledge producers when they advocate a new mindset for approaching competitiveness and innovation in the context of cities. The political imaginary of competition now also encompasses local innovation: cities are competing with one another like nation states do.

Subjectification through references to history makes the case for change, pointing to historical times where cities were drivers of the global economy. The perceived contemporary challenges of city competitiveness are linked with urbanization in the past. 
However, in the current imaginaries of global cities, urbanization is conflated with competition (Kangas, 2017; The Mori Memorial Foundation, 2015, Chapter Preface). Such use of history evokes invented traditions that provide seeming help and horizons of expectations for navigating the uncertain future (Hobsbawm, 1987; Koselleck, 2004), as the extract from a WEF report demonstrates.

"For most people, the map of the global economy that comes to mind is of nation states interconnected through flows of trade, capital, people and technology. However, before the ascendancy of the Westphalian nation state in 1648 , the primary political, economic and cultural unit was the city. An alternative map of the global economy comes to mind: one of cities connected across land borders, seas and oceans through the exchange of goods and services, foreign direct investment, migrant and short-term workers, and border-hopping technology." (World Economic Forum, 2014b, p. 7) (emphasis added)

In effect, the organizations that have produced country rankings in the past, are sustaining the potential critique of missing out grass-roots development by producing new assessments on the competitiveness and innovation of cities (A.T. Kearney, 2015, p. 6; World Economic Forum, 2014a, Chapter Preface). They argue for a continuity of their work, that also seems justified in conceptual terms, as the comparative assessments on city level mostly share the premises and causal assumptions of previous global rankings.

The new city level comparisons draw ideas from earlier measurements of good governance, but also build on comparisons of educational systems and higher education institutions. Here the notions of good governance and education merge into the concepts of innovation and competitiveness, also apparent in the historical narratives and political imaginaries. For 
example, in its work on Competitiveness of Cities the World Economic Forum refers to education under the label of soft connectivity. Understood broadly as social capital, another element of soft-connectivity is 'open society' that finds a historical reference point in premodern era.

"[Soft connectivity] concerns an atmosphere of tolerance, free expression and cosmopolitanism, all characteristics of what the philosopher Sir Karl Popper called the “open society". Today, they are highly conducive to the generation and dissemination of ideas, and to entrepreneurship, innovation and economic growth, just as they were in cities at the heart of the pre-modern European and Asian "miracles"." (World Economic Forum, 2014b, p. 13)

Use of history highlights subjectification, where the measurement of cities not only renders them governable but also links identities to proposed action (cf. Kangas, 2017). This becomes apparent in the WEF 2016 White Paper that highlights policies that can be put in place to enhance competitiveness of cities in connection to global value chains (World Economic Forum, 2016). As constructed by the rankings, competitiveness implies firm institutional conditions and innovation environments with established ties between research institutions and private companies, an "open society", and openness through global connectivity and information flows, as well as high ranking universities with excellent research performance and merited scholars (especially in science and engineering), availability of educated workforce and ability to recruit it from abroad.

Indeed, in just a few years many organizations have shifted their focus towards measuring cities. Despite the abundant referencing to the historical processes of urbanization, there is 
also undoubtedly great awareness of other ranking producers' activities in the field. Although the measurements have emerged over a relatively short period, they are still able to argue for the novelty of their products, and not necessarily compelled to enter the methodological critique of existing products. As such, the argument for a need to focus on cities implies a critique of the country rankings. At the same time, the new rankings in many ways echo the previous ideas and concepts of competitiveness. One aspect that is on the rise is the role of knowledge and education, but also here the perceptions are very conventional and link strongly to the policy scripts embodied in the global university rankings.

\section{Conclusions}

Analyzing emerging city-level indicators, we have explored what added value the new rankings of innovation have, considering also their recent focus on local level, and what implications this has for governance of innovation. We have identified ideational shifts of innovation that highlight intense coupling of higher education and economic competitiveness: the indicators now firmly tie local innovation and higher education with global competitiveness. These shifts are important as quantification objectifies 'local innovation', rendering it governable and open for policy intervention. Furthermore, along with objectification, the indicators acquire their governance effects through subjectification: urban actors and entities come to acquire socially constructed identities that are further linked with calls for action.

As the measurements on competitiveness and innovation now concern regions and cities, the focus is increasingly turning towards the performance of higher education institutions. Indeed, higher education institutions reside predominantly in urban environments, making them a logical element in the assessments of innovative and competitive cities. This is now 
reflected in their measurements of human capital, research and development, and talent. These new rankings objectify higher education as an element of city competitiveness and innovation, now deemed elementary for global competitiveness.

University rankings provide a logical bridge for the move towards 'local innovation'. Mostly based in major urban areas, the higher education institutions measured by the standing global university rankings are used in the composite indicators of innovation, or their methodology is copied. We see new actors entering the field of measurement with city-level data sets, while some of the established global index producers are also reassessing their focus. In principle, the regional and city-level measurements provide an alternative to global rankings in terms of the locus of their analysis. Still we see no major changes in the conceptualization of competitiveness and innovation, but rather incremental changes.

The emerging comparative assessments of local innovation are trapped by existing measurements in two senses. First, there is an ontological trap (Kauppi \& Erkkilä, 2011, pp. 314-315): as rankings have become such a central element of transnational governance, it would be very difficult to gain visibility for comparative assessment without resorting to quantification. Second, and more important for our analysis, there now is a strong convergence between the data sets. To enter the field of ranking the actors adopt many existing practices and ideas prevailing in the field. In addition, there is also keen exchange of data. Consequently, the new indicators entering the field of measurement further strengthen the established order instead of providing alternatives to it.

Overall, the role of knowledge is becoming more central for the measurements and the indicators have helped to construct a global policy script on knowledge governance that 
traverses countries, regions and cities. Through subjectification, the cities and universities are now deemed responsible for economic performance through innovation and drawn into global competition. But despite of their adopted rhetoric of grand narratives emphasizing a revolution in city level innovation and competitiveness, the producers of city level indicators publish figures that largely overlap with previous measurements both conceptually and in terms of data sources. While the policy feed is becoming more regionally focused, the underlying ideas of economic competitiveness remain dominant, now merely projected on a new level of analysis with help of university rankings.

The implications for higher education and innovation are indirect, but the attributes of these measurements stress universities' research output (peer-reviewed journal articles), highlight the number of patents as an indicator of innovativeness, reward universities' increased collaboration with private sector, emphasize certain disciplines (such as engineering), and value the availability of educated work force as well as the ability to attract and retain it. These attributes obtain governance effects through objectification, rendering them as policy concerns that are further linked to calls for action through subjectification that now portrays urban actors as responsible for local innovation amid global competition of epic proportions.

The instrumental rationality of measuring innovation and its self-reinforcing qualities bear resemblance to the Weberian bureaucratic logic that left no room for value rationality and ethical considerations (Weber, 1978). To Weber the way to escape such constellation was politics. To politicize the numerical transnational policy scripts of global competitiveness and innovation, one needs to bring their methodological limitations and ideological underpinnings to light. This would also mark an opening for contesting the calculative logic of global competitiveness and local innovation. 
References

Alasuutari, P., Rautalin, M., \& Syväterä, J. (2015). Organisations as Epistemic Capital: the Case of Independent Children's Rights Institutions. International Journal of Politics, Culture, and Society, 29(1), 57-71. https://doi.org/10.1007/s10767-015-9205-3

A.T. Kearney. (2014). 2014 Global Cities Index and Emerging Cities Outlook. Global Cities, Present and Future. A.T. Kearney.

A.T. Kearney. (2015). Global Cities 2015: The Race Accelerates. A.T. Kearney.

Baert, P. (1991). Unintended Consequences: A Typology and Examples. International Sociology, 6(2), 201-210. https://doi.org/10.1177/026858091006002006

Broome, A., Homolar, A., \& Kranke, M. (2018). Bad science: International organizations and the indirect power of global benchmarking. European Journal of International Relations, 24(3), 514-539. https://doi.org/10.1177/1354066117719320

Cornell University, INSEAD and WIPO. (2015). The Global Innovation Index 2015: Effective Innovation Policies for Development. World Intellectual Property Organization.

Desrosières, A. (1998). The Politics of Large Numbers: A History of Statistical Reasoning. Cambridge: Harvard University Press.

Erkkilä, T., \& Piironen, O. (2014). (De)politicizing good governance: the World Bank Institute, the OECD and the politics of governance indicators. Innovation: The European Journal of Social Science Research, 27(4), 344-360.

https://doi.org/10.1080/13511610.2013.850020

Erkkilä, T., \& Piironen, O. (2018). Rankings and Global Knowledge Governance: Higher Education, Innovation and Competitiveness. New York, NY: Palgrave Macmillan. 
Espeland, W. N., \& Sauder, M. (2007). Rankings and Reactivity: How Public Measures Recreate Social Worlds. American Journal of Sociology, 113(1), 1-40. https://doi.org/10.1086/517897

European Commission. (2016). European Innovation Scoreboard 2016. European Commission.

Freistein, K. (2016). Effects of Indicator Use: A Comparison of Poverty Measuring Instruments at the World Bank. Journal of Comparative Policy Analysis: Research and Practice, 18(4), 366-381. https://doi.org/10.1080/13876988.2015.1023053

Giddens, A. (1984). The Constitution of Society: Outline of the Theory of Structuration. Cambridge: Polity Press.

Gieryn, T. F. (1983). Boundary-Work and the Demarcation of Science from Non-Science: Strains and Interests in Professional Ideologies of Scientists. American Sociological Review, 48(6), 781-795. https://doi.org/10.2307/2095325

Grek, S. (2013). Expert moves: international comparative testing and the rise of expertocracy. Journal of Education Policy, 28(5), 695-709. https://doi.org/10.1080/02680939.2012.758825

Haas, P. M. (1992). Introduction: Epistemic Communities and International Policy Coordination. International Organization, 46(1), 1-35.

Hazelkorn, E. (2011). Rankings and the Reshaping of Higher Education: The Battle for World-Class Excellence. Palgrave Macmillan.

Hobsbawm, E. (1987). Introduction: Inventing Traditions. In E. Hobsbawm \& T. Ranger (Eds.), The Invention of Tradition. Cambridge University Press.

Hoffmann, M. (2011). Disciplinary power. In D. Taylor (Ed.), Michael Foucault: key concepts. Durham: Acumen. 
Kangas, A. (2017). Global Cities, International Relations and the Fabrication of the World. Global Society, O(0), 1-20. https://doi.org/10.1080/13600826.2017.1322939

Kauppi, N., \& Erkkilä, T. (2011). The Struggle Over Global Higher Education: Actors, Institutions, and Practices. International Political Sociology, 5(3), 314-326.

Kehm, B. M., \& Stensaker, B. (2009). University Rankings, Diversity, and the New Landscape of Higher Education. Sense Publishers.

Kelley, J. G., \& Simmons, B. A. (2015). Politics by Number: Indicators as Social Pressure in International Relations. American Journal of Political Science, 59(1), 55-70. https://doi.org/10.1111/ajps.12119

Knack, S., Kugler, M., \& Manning, N. (2003). Second-Generation Governance Indicators. International Review of Administrative Sciences, 69(3), 345-364. https://doi.org/10.1177/0020852303693004

Koselleck, R. (2004). Futures Past: On the Semantics of Historical Time. New York: Columbia University Press.

Langbein, L., \& Knack, S. (2010). The Worldwide Governance Indicators: Six, One, or None? Journal of Development Studies, 46(2), 350-370. https://doi.org/10.1080/00220380902952399

Lawler, S. (2014). Identity: Sociological Perspectives (2nd edition). Cambridge: Polity Press.

Leff, S., \& Petersen, B. (2015). Beyond the Scorecard: Understanding Global City Rankings. The Chicago Council on Global Affairs.

Lim, M. A. (2018). The building of weak expertise: the work of global university rankers. Higher Education, 75(3), 415-430. https://doi.org/10.1007/s10734-017-0147-8

Löwenheim, O. (2008). Examining the State: a Foucauldian perspective on international “governance indicators.” Third World Quarterly, 29(2), 255-274. https://doi.org/10.1080/01436590701806814 
Marginson, S. (2008). Global field and global imagining: Bourdieu and worldwide higher education. British Journal of Sociology of Education, 29(3), 303-315.

Mastercard. (2008). Worldwide Centers of Commerce Index. Mastercard.

Merry, S. E., Davis, K. E., \& Kingsbury, B. (Eds.). (2015). The Quiet Power of Indicators. New York, NY: Cambridge University Press.

Miller, P., \& Rose, N. (1990). Political Rationalities and Technologies of Government. In S. Hänninen \& K. Palonen (Eds.), Texts, Contexts, Concepts. Studies on Politics and Power in Language. Helsinki: The Finnish Political Science Association.

Mittelman, J. H. (2017). Implausible Dream: The World-Class University for Repurposing Higher Education. Princeton: Princeton University Press.

Paola Annoni, Dijkstra, L., \& Gargano, N. (2017). The EU Regional Competitiveness Index 2016. Working Paper 02/2017. Retrieved from http://ec.europa.eu/regional_policy/sources/docgener/work/201701_regional_competit iveness2016.pdf

Porter, T. M. (1996). Trust in Numbers. Princeton: Princeton University Press.

Power, M. (2003). Evaluating the Audit Explosion. Law \& Policy, 25(3), 185-202. https://doi.org/10.1111/j.1467-9930.2003.00147.x

Robson, K. (1992). Accounting numbers as "inscription": Action at a distance and the development of accounting. Accounting, Organizations and Society, 17(7), 685-708. https://doi.org/10.1016/0361-3682(92)90019-O

Rose, N., \& Miller, P. (2008). Governing the Present: Administering Economic, Social and Personal Life (1 edition). Cambridge Malden: Polity.

The Economist Intelligence Unit. (2013). Hot Spots 2025. Benchmarking the future competitiveness of cities. The Economist Intelligence Unit. 
The Mori Memorial Foundation. (2015). Global Power City Index 2015. Summary. The Mori Memorial Foundation.

The Mori Memorial Foundation. (2016). The Global Power City Index. Yearbook. The Mori Memorial Foundation.

Weber, M. (1978). Economy and Society (Vol. 1 and 2). Berkeley: University of California Press.

World Economic Forum. (2014a). Global Competitiveness Report 2014-2015. Retrieved from http://www3.weforum.org/docs/WEF_GlobalCompetitivenessReport_2014-15.pdf

World Economic Forum. (2014b). The Competitiveness of Cities. A report of the Global Agenda Council on Competitiveness. World Economic Forum.

World Economic Forum. (2016). White Paper Competitive Cities and their Connections to Global Value Chains. Retrieved from http://www3.weforum.org/docs/WEF_2016_WhitePaper_GAC_Competitive_Cities_. pdf 
Table 1 Data Producers of Global Competitiveness Index (GCI) and Global Innovation Index (GII) and Global Talent Competitiveness Index (GTCI)

\begin{tabular}{|l|l|l|l|l|l|l|l|l|}
\hline \multirow{2}{*}{ Source } & \multicolumn{2}{|l|}{ GCI } & \multicolumn{2}{l|}{ GII } & \multicolumn{2}{l|}{ Overall } \\
\cline { 2 - 9 } & $\begin{array}{l}\text { Number of } \\
\text { variables }\end{array}$ & $\begin{array}{l}\text { Share of } \\
\text { all } \\
\text { variables }\end{array}$ & $\begin{array}{l}\text { Number of } \\
\text { variables }\end{array}$ & $\begin{array}{l}\text { Share of } \\
\text { all } \\
\text { variables }\end{array}$ & $\begin{array}{l}\text { Number of } \\
\text { variables }\end{array}$ & $\begin{array}{l}\text { Share of } \\
\text { all } \\
\text { variables }\end{array}$ & $\begin{array}{l}\text { Number of } \\
\text { variables }\end{array}$ & $\begin{array}{l}\text { Share of } \\
\text { all } \\
\text { variables }\end{array}$ \\
\hline World Economic Forum & 82 & $71.9 \%$ & 5 & $6.1 \%$ & 23 & $35.4 \%$ & 110 & $42.1 \%$ \\
\hline World Bank & 10 & $8.8 \%$ & 17 & $20.7 \%$ & 13 & $20.0 \%$ & 40 & $15.3 \%$ \\
\hline UNESCO & 3 & $2.6 \%$ & 14 & $17.1 \%$ & 9 & $13.8 \%$ & 26 & $10.0 \%$ \\
\hline IMF & 5 & $4.4 \%$ & 3 & $3.7 \%$ & 0 & $0.0 \%$ & 8 & $3.1 \%$ \\
\hline ITU & 6 & $5.3 \%$ & 2 & $2.4 \%$ & 1 & $1.5 \%$ & 9 & $3.4 \%$ \\
\hline WTO & 2 & $1.8 \%$ & 6 & $7.3 \%$ & 0 & $0.0 \%$ & 8 & $3.1 \%$ \\
\hline United Nations & 0 & $0.0 \%$ & 7 & $8.5 \%$ & 1 & $1.5 \%$ & 8 & $3.1 \%$ \\
\hline WIPO & 1 & $0.9 \%$ & 6 & $7.3 \%$ & 0 & $0.0 \%$ & 7 & $2.7 \%$ \\
\hline ILO & 1 & $0.9 \%$ & 2 & $2.4 \%$ & 5 & $7.7 \%$ & 8 & $3.1 \%$ \\
\hline Thomson Reuters & 0 & $0.0 \%$ & 3 & $3.7 \%$ & 0 & $0.0 \%$ & 3 & $1.1 \%$ \\
\hline Sum & 110 & $96.5 \%$ & 65 & $79.3 \%$ & 52 & $80 \%$ & 227 & $87 \%$ \\
\hline
\end{tabular}


Table 2: Competitiveness Assessments: City and Regional Level

\begin{tabular}{|c|c|c|c|c|c|c|c|}
\hline & $\begin{array}{l}\text { Worldwide Centers of } \\
\text { Commerce Index }\end{array}$ & $\begin{array}{l}\text { A.T. Kerneys Global } \\
\text { Cities }\end{array}$ & $\begin{array}{l}\text { Global Power City } \\
\text { Index }\end{array}$ & $\begin{array}{l}\text { EU regional } \\
\text { competitiveness } \\
\text { index }\end{array}$ & Hot Spots 2025 & $\begin{array}{l}\text { The Startup } \\
\text { Ecosystem Report }\end{array}$ & $\begin{array}{l}\text { The } \\
\text { Competitiveness of } \\
\text { Cities }\end{array}$ \\
\hline Producer & $\begin{array}{l}\text { MasterCard, 2007- } \\
2008\end{array}$ & A.T. Kerney, 2008- & $\begin{array}{l}\text { The Mori Memorial } \\
\text { Foundation, 2008- }\end{array}$ & $\begin{array}{l}\text { EU Joint Research } \\
\text { Centre, 2010, 2013, } \\
2016\end{array}$ & $\begin{array}{l}\text { The Economist } \\
\text { (intelligence Unit), } \\
2013\end{array}$ & $\begin{array}{l}\text { CrunchBase, } \\
\text { Compass, 2012, } \\
\text { 2015, } 2017\end{array}$ & WEF, 2014 \\
\hline Focus & $\begin{array}{l}\text { Role of leading cities } \\
\text { in global economy ( } 75 \\
\text { cities) }\end{array}$ & $\begin{array}{l}\text { City performance and } \\
\text { outlook (125 cities) }\end{array}$ & $\begin{array}{l}\text { City "magnetism" } \\
\text { (40 cities) }\end{array}$ & $\begin{array}{l}\text { Competitiveness of } \\
\text { EU regions }\end{array}$ & $\begin{array}{l}\text { City } \\
\text { competitiveness } \\
(120 \text { cities })\end{array}$ & $\begin{array}{l}\text { Startup ecosystems } \\
\text { of metropolitan } \\
\text { cities or } \\
\text { geographic areas } \\
\text { with a shared pool } \\
\text { of resources ( } 40 \\
\text { ecosystems) }\end{array}$ & $\begin{array}{l}\text { City } \\
\text { competitiveness } \\
\text { ( } 33 \text { cities) }\end{array}$ \\
\hline Assessment & $\begin{array}{l}\text { Index and ranking } \\
\text { based on seven } \\
\text { dimensions: } \\
\text { 1. Legal and political } \\
\text { framework } \\
\text { 2. Economic stability } \\
\text { 3. Ease of doing } \\
\text { business } \\
\text { 4. Financial flow } \\
\text { 5. Business center } \\
\text { 6. Knowledge creation } \\
\text { and information flow } \\
\text { 7. Liveability } \\
43 \text { indicators and } 74 \\
\text { sub-indicators }\end{array}$ & $\begin{array}{ll}\text { Global Cities Index: } \\
\text { 1. } & \text { Business activity } \\
\text { 2. Human Capital } \\
\text { 3. Information } \\
\text { exchange } \\
\text { 4. }\end{array}$ & $\begin{array}{l}\text { Index and ranking } \\
\text { based on six } \\
\text { functions } \\
\text { 1. Economy } \\
\text { 2. Research and } \\
\text { Development } \\
\text { 3. Cultural } \\
\text { Interaction } \\
\text { 4. Liveability } \\
\text { 5. Environment } \\
\text { 6. Accessibility }\end{array}$ & 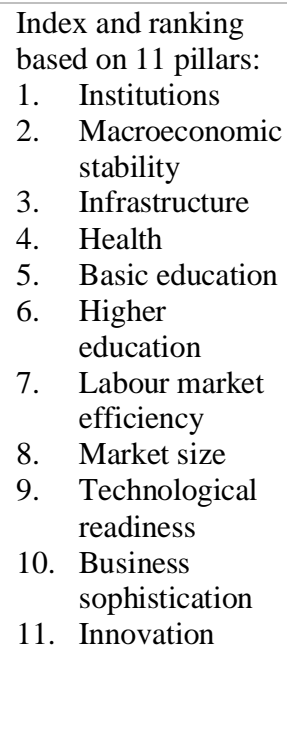 & 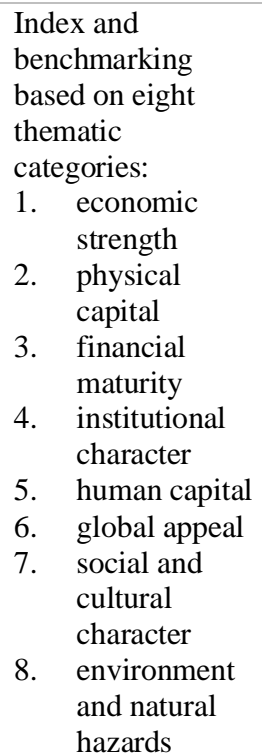 & $\begin{array}{ll}\text { Index based on } \\
\text { five components: } \\
\text { 1. } & \text { Performance } \\
\text { 2. } & \text { Funding } \\
\text { 3. } & \text { Talent } \\
\text { 4. } & \text { Market Reach } \\
\text { 5. } & \text { Startup } \\
& \text { experience }\end{array}$ & $\begin{array}{l}\text { Case studies } \\
\text { assessing four } \\
\text { mutually } \\
\text { interacting factors: } \\
\text { 1. Institutions } \\
\text { 2. Policies and } \\
\begin{array}{l}\text { regulation of } \\
\text { the business } \\
\text { environment }\end{array} \\
\text { 3. Hard } \\
\text { connectivity } \\
\text { 4. } \begin{array}{l}\text { Soft } \\
\text { connectivity }\end{array}\end{array}$ \\
\hline
\end{tabular}


Table 3: Innovation Rankings: Regional and City Level

\begin{tabular}{|c|c|c|c|c|c|c|}
\hline & $\begin{array}{l}\text { European Innovation } \\
\text { Scoreboard (EIS) / } \\
\text { Innovation Union } \\
\text { Scoreboard }\end{array}$ & $\begin{array}{l}\text { Global Innovation } \\
1000\end{array}$ & $\begin{array}{l}\text { Innovation Cities } \\
\text { Index }\end{array}$ & $\begin{array}{l}\text { Top } 100 \\
\text { Global Innovators }\end{array}$ & $\begin{array}{l}\text { Top } 100 \text { Innovative } \\
\text { Universities }\end{array}$ & $\begin{array}{l}\text { Top } 25 \text { Global } \\
\text { Innovators - } \\
\text { Government }\end{array}$ \\
\hline Producer & $\begin{array}{l}\text { The European } \\
\text { Commission, 2001- } \\
\text { 2008/ 2008- }\end{array}$ & $\begin{array}{l}\text { PwCand } \\
\text { Strategy\&, 2005- }\end{array}$ & 2thinknow, 2007- & $\begin{array}{l}\text { Reuters \& Thomson } \\
\text { Reuters Intellectual } \\
\text { Property \& Science, } \\
\text { 2011-2015 } \\
\text { Clarivate Analytics, } \\
\text { 2016- }\end{array}$ & $\begin{array}{l}\text { Reuters \& Thomson } \\
\text { Reuters Intellectual } \\
\text { Property \& Science, } \\
\text { 2015, } 2016\end{array}$ & $\begin{array}{l}\text { Reuters \& Thomson } \\
\text { Reuters Intellectual } \\
\text { Property \& Science, } \\
2016,2017\end{array}$ \\
\hline Focus & $\begin{array}{l}\text { Innovation } \\
\text { performance of EU } \\
\text { member } \\
\text { states/regions }\end{array}$ & $\begin{array}{l}\text { Flows of R\&D } \\
\text { spending among } \\
\text { companies and } \\
\text { countries (1000 } \\
\text { highest spending } \\
\text { companies } \\
\text { globally) }\end{array}$ & $\begin{array}{l}\text { Cities potential as } \\
\text { innovation } \\
\text { economies ( } 445 \\
\text { cities) }\end{array}$ & $\begin{array}{l}\text { Innovative companies } \\
\text { based on patent and } \\
\text { citation data (top } 100 \\
\text { listed) }\end{array}$ & $\begin{array}{l}\text { Ranking of (top 100) } \\
\text { universities based on } \\
\text { patent and scientific- } \\
\text { literature metrics. }\end{array}$ & $\begin{array}{l}\text { Publicly funded } \\
\text { institutions (top 25) } \\
\text { advancing science and } \\
\text { technology }\end{array}$ \\
\hline Assessment & $\begin{array}{l}\text { Index: } \\
\text { Enablers } \\
\text { 1. HR } \\
\text { 2. Open, excellent } \\
\quad \text { research systems } \\
\text { 3. Finance and } \\
\quad \text { support } \\
\text { Firm activities } \\
\text { 4. Firm investment } \\
\text { 5. Linkages \& } \\
\text { entrepreneurship } \\
\text { 6. Intellectual issues } \\
\text { Outputs } \\
\text { 7. Innovators } \\
\text { 8. Economic effects }\end{array}$ & $\begin{array}{l}\text { Ranking based on } \\
\text { R\&D spending }\end{array}$ & $\begin{array}{l}\text { Index based on three } \\
\text { factors: cultural } \\
\text { assets, human } \\
\text { infrastructure and } \\
\text { networked markets } \\
\\
31 \text { segments and } \\
162 \text { indicators }\end{array}$ & $\begin{array}{l}\text { Ranking based on } \\
\text { patent } \\
\text { and citation data } \\
\text { assessed across four } \\
\text { main criteria: } \\
\text { 1. Volume } \\
\text { 2. Success } \\
\text { 3. Globalization } \\
\text { 4. Influence }\end{array}$ & $\begin{array}{l}\text { Ranking based on } \\
\text { articles in scholarly } \\
\text { journals and patent } \\
\text { applications filed by } \\
\text { the institution }\end{array}$ & $\begin{array}{l}\text { Ranking based on } \\
\text { articles in scholarly } \\
\text { journals and patent } \\
\text { applications filed by } \\
\text { the institution }\end{array}$ \\
\hline
\end{tabular}

